\title{
Evaluation of the Actual Chlorine Concentration and the Required Time for Pulp Dissolution Using Different Naocl Irrigating Solutions
}

\author{
Alfredo Iandolo ${ }^{1}$, Alberto Dagna ${ }^{2}$, Riccardo Beltrami ${ }^{2}$, Claudio Poggio ${ }^{2}$, Mariano \\ Malvano ${ }^{1}$, Massimo Amato ${ }^{3}$, Dina Abdellatif ${ }^{4}$ \\ ${ }^{1}$ Department of Neurosciences, Reproductive and Odontostomatological Sciences, \\ University of Naples, Federico II, Naples, Italy \\ ${ }^{2}$ Department of Clinical, Surgical, Diagnostic and Pediatric Sciences - Section of \\ Dentistry, Endodontic Unit, University of Pavia, Italy \\ ${ }^{3}$ Department of Medicine and Surgery, University of Salerno, Salerno, Italy \\ 4 Department of Endodontics, Faculty of Dentistry, University of Alexandria, \\ Alexandria, Egypt
}

\section{ABSTRACT \\ INTRODUCTION}

The goal of root canal treatment is to shape and clean the endodontic space, reducing the bacterial load and removing the pulp tissue. Obviously, the action of the endodontic instruments is limited to the main canals, regardless of the complexity of the endodontic space. Consequently, finding the best possible cleaning technique, which can be obtained chemically using irrigation solutions, is a fundamental aid in the endodontic therapy. One of the most commonly used root canal irrigant is sodium hypochlorite $(\mathrm{NaOCl})$, available in various commercial formulations. The effectiveness of $\mathrm{NaOCl}$ is undeniable. However, the action of dissolution of the pulp tissue is merely dependent on the concentration and the characteristics of the irrigant itself. 
AIM

The aim of this study is to evaluate the effective concentration of different commercial formulas of sodium hypochlorite, by evaluating the percentage of total chlorine in each product. The dissolution capacity of the pulp tissue of each of the tested products was then analyzed by measuring the required time.

\section{MATERIALS AND METHODS}

Three commercial types of sodium hypochlorite were selected for this study: 5\% $\mathrm{NaOCl}$ (ACE, Procter \& Gamble), 5\% NaOCl (N5, Simit Dental) and 6\% $\mathrm{NaOCl}$ (CanalPro, Coltene). For each product, 10 packages were used, from which samples of the product were taken and $30 \times 5 \mathrm{ml}$ tubes were filled. All samples were divided into 3 groups and were analyzed using the DIN EN ISO 7393-2 method and the percentage of total chlorine (expressed as a percentage) was calculated.

40 samples of vital pulp were obtained from teeth freshly extracted for periodontal reasons and stored in physiological solution. In order to unify the size and weight of the samples (0.0001 mg), a microtome and a precision balance (Pro Explorer Ohaus) were used. Each sample, carefully examined by stereomicroscope (40x), was placed in artificial plastic containers and submerged in $0.1 \mathrm{ml}$ of irrigating solution at room temperature $\left(26^{\circ} \mathrm{C}\right)$.

A fourth control group used saline solution as irrigant. Simultaneously with the insertion of the irrigating solution, a digital stopwatch was activated and the time necessary for the complete dissolution of the pulp sample was measured.

The data obtained were subjected to statistical analysis. 


\section{RESULTS}

The average percentages of chlorine detected for each group were: $4.26 \%$ (ACE), $5.16 \%(\mathrm{~N} 5)$ and $5.97 \%$ (CanalPro).

The Kruskal-Wallis test showed statistically significant differences between the different commercial formulations of hypochlorite $(\mathrm{P}<0.05)$. CanalPro showed the lowest values, while ACE showed the highest values of dissolution time of the pulp.

\section{DISCUSSION}

The analysis of the total chlorine percentage found that the actual concentration of the sodium hypochlorite in the samples is close to the values declared by the manufacturers both in the case of N5 and CanalPro. On the contrary, the concentration detected in the samples of common bench bleach (ACE) is significantly lower, which has average values less than $5 \%$. This explains the longer time taken for the complete dissolution of the pulp tissue. The average dissolution time of the pulp samples was in fact inversely proportional to the concentration detected in the tested irrigants, so that a lower time corresponds to a higher concentration.

Keywords: Endodontic treatment, Irrigant activation, bacteria, biofilm, Sodium Hypochlorite

\section{INTRODUCTION}

Endodontic therapy is based on cleaning, shaping and sealing the root canal system (1): the main objectives are the complete dissolution of residual pulpal tissue, elimination of bacteria from the root canals, and the prevention of recontamination after treatment (2-5). The complex anatomy of the root canals limits the mechanical action of endodontic instruments: instruments can shape the canal, but true cleaning relies on irrigants. To increase efficacy of mechanical preparation and bacteria removal, instrumentation must be supplemented with active irrigating solutions. The use of chemical solution with bacteriostatic or bactericidal capabilities and tissue- 
dissolving attributes is recommended in order to facilitate the debridement and the cleaning of the root canal space. Irrigating solutions are considered to be essential for successful endodontic treatment (6-10). Mechanical preparation cannot effectively eliminate bacteria from the root canal system $(11,12)$. The objectives of irrigation are both mechanical and biologic (13): the mechanical purpose involves flushing out debris, lubricating the canal and dissolving organic and inorganic tissue; the biologic function is related to their antimicrobial effect. Nevertheless, even if it is a highly effective antimicrobial agent, it does not remove the smear layer from the dentin walls (14-21). $\mathrm{NaOCl}$ shows antiseptic properties due to the formation of hypochlorous acid and the subsequent release of chlorine, which is a very active bactericide (1). Free chlorine in $\mathrm{NaOCl}$ dissolves necrotic tissue by breaking down proteins into amino acids; to obtain this effect concentrations ranging from $0.5 \%$ to $5.25 \%$ have been recommended (1). Manipulations that enhance the efficacy of $\mathrm{NaOCl}$ include warming the solution (21): increasing the temperature from $22^{\circ} \mathrm{C}$ to $45^{\circ} \mathrm{C}$ has been shown to improve both tissue dissolution ability and antibacterial action $(22,23)$.

Endodontic failure may occur in cases of persistent bacteria in the root canal system (24). Endodontic pathogens have developed a variety of strategies to survive in adverse conditions. They may invade dentinal tubules and persist in superficial layers of dentin adjacent to the canal lumen $(25,26)$ and they may organize as biofilms, complex sessile communities performing numerous adaptive changes in behavior that increase their resistance to a variety of chemotherapeutic agents compared with their planktonic counterparts (27). Since the persistence of a bacterial burden at the time of obturation appears strictly related to the failure of the treatment $(28,29)$, there is a strong need to improve the efficacy of disinfecting procedures in endodontic therapy. Other than conventional irrigation, additional techniques for endodontic disinfection have been proposed and tested; recently several devices for endodontic irrigation have been introduced in order to minimize or eliminate residual bacteria in the root canal.

$\mathrm{NaOCl} 5 \%$ has been recommended as an irrigating solution in the treatment of infected root canals because of its well-known bactericidal action; it is effective in aiding the mechanical flushing of debris from root canals, dissolving organic matter and it has a broad spectrum of antimicrobial activity (30). $\mathrm{NaOCl}$ effectively eliminates microbes from root canals (7-11). No agreement has been reached yet regarding the correct concentration for the use in endodontics; the right concentration is a compromise between its antibacterial activity and its cytotoxicity. Bystrom \& 
Sundqvist in 1983 (15) suggested the use of $0.5 \% \mathrm{NaOCl}$ in order to minimize cytotoxicity; but some doubt has been casted on the effectiveness of $0.5 \% \mathrm{NaOCl}$ (19). The disinfecting efficiency depends on the concentration, which ranges from $0.5 \%$ to $5.25 \%$. Radcliffe et al (30) evaluated the in vitro antimicrobial activity of varying concentrations of $\mathrm{NaOCl}$ versus different microorganisms. They observed that E. faecalis, the most resistant to $\mathrm{NaOCl}$, reduced its $\mathrm{CFU} / \mathrm{ml}$ to zero when exposed to $0.5 \% \mathrm{NaOCl}$ for $30 \mathrm{~min}$, to $1.0 \% \mathrm{NaOCl}$ for $10 \mathrm{~min}$, to $2.5 \% \mathrm{NaOCl}$ for 5 $\min$ or to $5.25 \% \mathrm{NaOCl}$ for $2 \mathrm{~min}$. Similar results were obtained by Gomes et al (31): they showed that $0.5 \% \mathrm{NaOCl}$ took $30 \mathrm{~min}$ to destroy bacterial cells of E. faecalis, while $5.25 \% \mathrm{NaOCl}$ requires less than $30 \mathrm{~s}$ to obtain the same results; so they concluded that $5.25 \%$ is the ideal and the most effective concentration.

This study aimed to evaluate the effective concentration of different commercial formulations of sodium hypochlorite, by evaluating the percentage of total chlorine in each product. For each of the tested products the dissolution capacity of the pulp tissue was then analyzed, measuring the necessary time.

\section{MATERIALS AND METHODS}

Three commercial types of sodium hypochlorite were selected for this study: 5\% $\mathrm{NaOCl}$ (ACE, Procter \& Gamble, USA), 5\% NaOCl (N5, Simit Dental, Italy) and 6\% $\mathrm{NaOCl}$ (CanalPro, Coltene, Swiss). For each product, 10 packages were used, from which samples of the product were taken and $30 \times 5 \mathrm{ml}$ tubes were filled. All samples were divided into 3 groups and were analyzed using the DIN EN ISO 7393-2 method and the percentage of total chlorine (expressed as a percentage) was calculated. 
40 samples of vital pulp were obtained from teeth freshly extracted for periodontal reasons and stored in physiological solution. Within two hours from the extraction the crown of the teeth was removed (using a laboratory diamond disk) and the pulp tissue was removed (using micro-tweezers). In order to unify the size and weight of the samples $(0.0001 \mathrm{mg})$, a microtome and a precision balance (Pro Explorer Ohaus) were used Fig. 1,2. Each sample, carefully examined by stereomicroscope (40x), was placed in artificial plastic containers and submerged in $0.1 \mathrm{ml}$ of irrigating solution at room temperature $\left(26^{\circ} \mathrm{C}\right)$ Fig. 3-8. A fourth control group used saline solution as irrigant. Simultaneously with the insertion of the irrigating solution, a digital stopwatch was activated and the time necessary for the complete dissolution of the pulp sample was measured.

The data obtained were subjected to statistical analysis using the Stata 12 software (StataCorp. 2011.Stata Statistical Software: Release 12. College Station, TX: StataCorp LP.). The Pearson correlation index was calculated between the percentage values of total chlorine present in each irrigant and the time values necessary for the complete dissolution of the pulp. The dissolution time values were analyzed with the Kruskal-Wallis non-parametric ANOVA test to evaluate any statistically significant differences between the different commercial formulations of sodium hypochlorite (P $<0.05)$.

\section{RESULTS}

The average percentages of chlorine detected for each group were: $4.26 \%$ (ACE), $5.16 \%(\mathrm{~N} 5)$ and $5.97 \%$ (CanalPro).

The average dissolution time of the samples of pulp measured was: $1331.76 \mathrm{sec}$ (22 min and $12 \mathrm{sec}$ ) for ACE, $1133.88 \mathrm{sec}(18 \mathrm{~min}$ and $54 \mathrm{sec})$ for N5, $1011.71 \mathrm{sec}$ (16 min and $52 \mathrm{sec}$ ) for CanalPro. Samples from the control group (saline) showed no dissolution reactions from the pulp. The Kruskal-Wallis test showed statistically 
significant differences between the different commercial formulations of hypochlorite ( $\mathrm{P}<0.05)$. CanalPro showed the lowest values, while ACE showed the highest values of dissolution time of the pulp.

\section{DISCUSSION AND CONCLUSIONS}

The main purpose of endodontic treatment is the removal, as complete as possible, of damaged tissues and bacteria from the complex endodontic system. The endodontic system is not simple but must be esteemed as a three-dimensional entity. In fact, it is not only composed of the main canal but also of lateral canals, ramifications, loops, isthmuses, deltas and dentinal tubules. So the cleaning phase must be active, it must be a three-dimensional cleansing, 3D cleaning, this to make sure that the irrigants can reach and act on pulp tissue and bacteria in most of these complex anatomies.

Naturally, bacteria are able to live either as independent free-floating cells (planktonic state) or be members of colonized surface-attached microbial communities known as biofilms. Biofilms consist of microorganisms that are imbedded in a self produced extracellular matrix which bind cells together $(32,33,34)$.

Biofilms have major clinical importance as they provide bacteria with shielding environments against physical traumas, immune responses of the host, antibacterial agents, and antibiotics $(35,36)$. After several years of thorough research, it is now well proven that biofilm formation is a developmental process that begins when a cell attaches to a surface and it is strictly regulated in response to environmental conditions (36). Briefly, formation of a bacterial biofilm is a progressive process that begins when a cell attaches to a surface. The formation of microbial biofilms includes several steps that can be divided in two main parts: the initial interactions of cells with the substrate and growth and development of the biofilm.

In root canals of teeth, biofilms have been confirmed by examinations of extracted teeth associated with periapical lesions (37), sections were viewed by transmission electron microscopy, showed dense aggregates of cocci and rods embedded in an extracellular matrix were observed along the walls ( 38 ), The manner in which 
biofilm grows contributes to resistance to host defenses, and within the biofilm, there are formed subpopulations of cells that are phenotypically highly resistant to antibiotics and biocides (39 , $40,41,42$ ). Although there is no overall agreement upon mechanism to explain this broad resistance to antimicrobials, the extent of the problem in Endodontics is significant.

To explain, biofilms initiate formation when a cell in planktonic state is deposited on a substratum coated with an organic conditioning polymeric matrix or "conditioning film”.

When the first bacterial cells arrive, there is a weak and reversible contact between the cell and the conditioning film. (43). The next step is when the adhesion of the cell to the substrate is now irreversible. This is partly due to surface attachments overcoming the repulsive forces between the two surfaces and also helped by the sticky exopolymers secreted by the cells. The second part of the formation of a biofilm includes its growth and development. Development of a biofilm occurs as a result of adherent cells replicating and by additional cells adhering to the biofilm (44). Biofilm bacteria usually have an increased resistance to antimicrobial agents, in some cases up to 1,000-fold greater than that of the same microorganisms living in liquid suspension $(45,46)$.

The reasons for the increased resistance of bacteria when forming a biofilm are believed to be multiple: physical and acquired mechanisms. The physical protection is mainly related to the impaired penetration of antibiotics through the biofilm matrix. While, acquired resistance consists of differentiation of cells with low metabolic activity, differentiation of cells that actively respond to stress, and differentiation of cells with a very high persistent phenotype.

Until now, the most common and efficient antibiofilm strategy used in root canal therapy is the removal with mechanical instrumentation and irrigant activation (47, $48,49,50)$.

Activation of irrigants via sonic, ultrasonic, internal heating or laser devices has shown great improvement in the cleaning and disinfection of the root canal system and should be considered an important fundamental step in non-surgical endodontic therapy $(51,52,53)$. 
Torabinejad and Walton (1) outlined the ideal properties of an endodontic irrigating solution: organic and inorganic tissue solvent, antimicrobial action, non-toxicity to periapical tissues, low surface tension, lubricant action. No one solution as yet possesses all the properties of an ideal irrigant. Sodium hypochlorite $(\mathrm{NaOCl})$ is still the most preferred irrigating solution, thanks to its numerous advantages: it is an excellent antibacterial agent, capable of dissolving necrotic tissue, vital pulp tissue and the organic components of dentin and biofilm; in addition, it is inexpensive, with a long shelf life, and it is easily available $(1,14)$.

In the current study, the analysis of the total chlorine percentage found that the actual concentration of the sodium hypochlorite in the samples is close to the values declared by the manufacturers both in the case of N5 and CanalPro. On the contrary, the concentration detected in the samples of common bench bleach (ACE) is significantly lower, which has average values less than $5 \%$. This explains the longer time taken for the complete dissolution of the pulp tissue. The average dissolution time of the pulp samples was in fact inversely proportional to the concentration detected in the tested irrigants, so that a lower time corresponds to a higher concentration.

In conclusion, it is important to use techniques that activate irrigants and above all, based on this study, use $\mathrm{NaOCl}$ products manufactured exclusively for Endodontics.

\section{TABLES}

\begin{tabular}{|c|c|c|c|}
\hline & Group 1 & Group 2 & Group 3 \\
\hline & ACE & N5 & CanalPro \\
\hline & 4,3 & 5,2 & 5,9 \\
\hline & 4,3 & 5,1 & 6,0 \\
\hline & 4,2 & 5,2 & 6,0 \\
\hline & 4,2 & 5,2 & 6,0 \\
\hline & 4,2 & 5,2 & 6,0 \\
\hline & 4,2 & 5,1 & 6,0 \\
\hline
\end{tabular}




\begin{tabular}{|c|c|c|c|}
\hline & 4,3 & 5,2 & 5,9 \\
\hline & 4,3 & 5,1 & 5,9 \\
\hline & 4,3 & 5,2 & 6,0 \\
\hline & 4,3 & 5,1 & 6,0 \\
\hline average & $\mathbf{4 , 2 6}$ & $\mathbf{5 , 1 6}$ & $\mathbf{5 , 9 7}$ \\
\hline
\end{tabular}

Table 1: chlorine values detected for each sample

\begin{tabular}{|l|c|c|c|c|}
\hline & Group 1 & Group 2 & Group 3 & Group 4 \\
\hline & ACE & N5 & CanalPro & control \\
\hline & 1317,54 & 1137,54 & 1014,32 & $/$ \\
\hline & 1344,45 & 1114,25 & 1018,52 & $/$ \\
\hline & 1365,22 & 1143,38 & 1035,44 & $/$ \\
\hline & 1312,44 & 1135,23 & 1022,34 & $/$ \\
\hline & 1354,55 & 1124,43 & 1005,28 & $/$ \\
\hline & 1287,24 & 1107,14 & 980,12 & $/$ \\
\hline & 1334,15 & 1124,25 & 998,51 & $/$ \\
\hline & 1304,12 & 1193,28 & 1025,14 & $/$ \\
\hline & 1342,44 & 1175,13 & 1012,14 & $/$ \\
\hline average & 1355,45 & 1084,13 & 1005,28 & $/$ \\
\hline
\end{tabular}

Table 2: dissolution time of pulp samples (expressed in seconds)

\section{REFERENCES}

1. Torabinejad M, walton RE. Endodontics. Principles and practice. St Louis, Missouri:

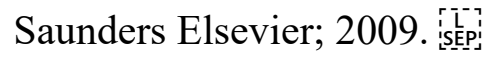

2. Abou-Rass M, Piccinino MV. The effectiveness of four clinical irrigation methods on the removal of root canal debris. Oral Surg Oral Med Oral Pathol. 1982;54(3):323-

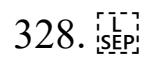

3. Briseno M BM, wirth R, Hamm G, Standhartfnger w. Efficacy of different irrigation methods and concentrations of root canal irrigation solutions on bacteria in the root canal. Dent Traumatol. 1992;8(1):6-11. doi:10.1111/j.1600-9657.1992. tb00218.x. [s-[ep] 
4. Kaplan AE, Picca M, Gonzalez MI, Macchi RL, Molga- tini SL. Antimicrobial effect of six endodontic sealers: an in vitro evaluation. Dent Traumatol. 1999;15(1):42-45.

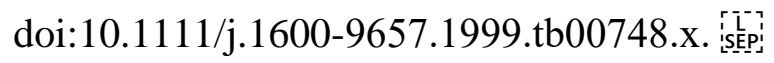

5. Mickel AK, Nguyen TH, Chogle S. Antimicrobial activity of endodontic sealers on Enterococcus faecalis. J Endod. 2003;29(4):257-258. doi:10.1097/00004770200304000- 00006. iscepi

6. Brown JI, Doran JE. An in vitro evaluation of the particle flotation capability of

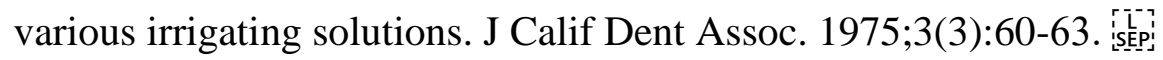

7. D'Arcangelo C, Varvara G, De Fazio P. An evaluation of the action of different root canal irrigants on facultative aerobic- anaerobic, obligate anaerobic, and microaerophilic bacteria. J Endod. 1999;25(5):351-353. doi:10.1016/S0099-

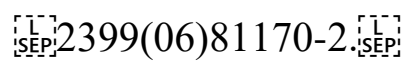

8. Jeansonne MJ, white RR. A comparison of $2.0 \%$ chlorhexidine gluconate and $5.25 \%$ sodium hypochlorite as antimicrobial endodontic irrigants. J Endod. 1994;20(6):276278. doi:10.1016/S0099-2399(06)80815-0.

9. Siqueira JF, Batista MM, Fraga RC, de Uzeda M. Antibacterial effects of endodontic irrigants on black-pigmented Gram-negative anaerobes and facultative bacteria. J Endod. 1998;24(6):414-416. doi:10.1016/S0099-2399(98)80023-X.

10. Sundqvist G, Figdor D, Persson S, Sjogren U. Microbiologic analysis of teeth with failed endodontic treatment and the outcome of conservative retreatment. Oral Surg Oral Med Oral Pathol. 1998;85(1):86-93.

11. Shabahang S, Pouresmail M, Torabinejad M. In vitro antimicrobial efficacy of MTAD and sodium hypochlorite. J Endod. 2003;29(7):450-452. doi:10.1097/00004770-200307000-00006.

12. yesilsoy C, whitaker E, Cleveland D, Phillips E, Trope M. Antimicrobial and toxic effects of established and potential root canal irrigants. J Endod. 1995;21(10):513515. doi:10.1016/ S0099-2399(06)80524-8.

13. Hargreaves KM, Cohen S. Pathways of the pulp. 10th edition. St Louis, Missouri: Mosby Elsevier; 2011.

14. Poggio C, Arciola CR, Dagna A, Chiesa M, Sforza D, Visai L. Antimicrobial activity of sodium hypochlorite-based irrigating solutions. Int J Artif Organs. 2010;33(9):654659.

15. Byström A, Sundqvist G. Bacteriologic evaluation of the effect of 0.5 percent sodium hypochlorite in endodontic therapy. Oral Surg Oral Med Oral Pathol. 1983;55(3):307- 
312. doi:10.1016/0030-4220(83)90333-X.

16. Mentz TCF. The use of sodium hypochlorite as a general endodontic medicament. Int Endod J. 1982;15(3):132-136. doi:10.1111/j.1365-2591.1982.tb01265.x. is[-pi

17. Ohara PK, Torabinejad M, Kettering JD. Antibacterial effects of various endodontic irrigants on selected anaerobic bacteria. Dent Traumatol. 1993;9(3):95-100.

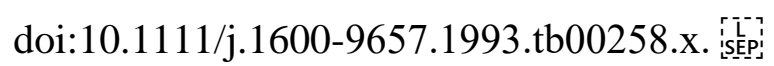

18. Shih M, Marshall FJ, Rosen S. The bactericidal efficiency of sodium hypochlorite as an endodontic irrigant. Oral Surg Oral Med Oral Pathol. 1970;29(4):613-619. doi:10.1016/0030- 4220(70)90473-1. [ičpi

19. Siqueira JF, MacHado AG, Silveira RM, Lopes HP, Uzeda M. Evaluation of the effectiveness of sodium hypochlorite used with three irrigation methods in the elimination of Enterococcus faecalis from the root canal, in vitro. Int Endod J. 1997;30(4):279-282. doi:10.1111/j.1365-2591.1997. tb00708.x. is ș-pi

20. Thè SD. The solvent action of sodium hypochlorite on fixed and unfixed necrotic tissue. Oral Surg Oral Med Oral Pathol. 1979;47(6):558-561. doi:10.1016/0030-

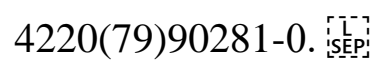

21. Türkün M, Cengiz T. The effects of sodium hypochlorite and calcium hydroxide on tissue dissolution and root canal cleanliness. Int Endod J. 1997;30(5):335-342.

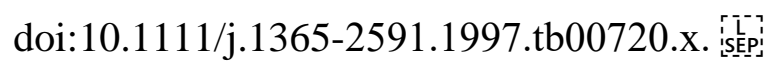

22. Sirtes G, waltimo T, Schaetzle M, Zehnder M. The effects of temperature on sodium hypochlorite short-term stability, pulp dissolution capacity, and antimicrobial efficacy. J Endod. 2005;31(9):669-671. doi:10.1097/01. don.0000153846.62144.d2. ín

23. Rossi-Fedele G, De Figueiredo JAP. Use of a bottle warmer to increase $4 \%$ sodium hypochlorite tissue dissolution ability on bovine pulp. Aust Endod J. 2008;34(1):39-

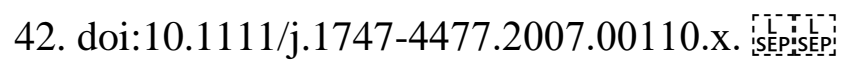

24. Siqueira JF Jr. Aetiology of root canal treatment failure: why well-treated teeth can fail. Int Endod J. 2001;34(1):1-10. doi:10.1046/j.1365-2591.2001.00396.x. is-pep

25. Peters LB, wesselink PR, Buijs JF, Vanwinkelhoff AJ. Viable bacteria in root dentinal tubules of teeth with apical periodontitis. J Endod. 2001;27(2):76-81. doi:10.1097/00004770- 200102000-00002. [išpi

26. Sen BH, Piskin B, Demirci T. Observation of bacteria and fungi in infected root canals and dentinal tubules by SEM. Dent Traumatol. 1995;11(1):6-9. doi:10.1111/j.1600-9657.1995. tb00671.x. ischep 
27. de Paz LC. Redefining the persistent infection in root canals: possible role of biofilm communities. J Endod. 2007;33(6):652-662. doi:10.1016/j.joen.2006.11.004.

28. Fabricius L, Dahlén G, Sundqvist G, Happonen RP, Möller ÅJR. Influence of residual bacteria on periapical tissue healing after chemomechanical treatment and root filling of experimentally infected monkey teeth. Eur J Oral Sci. 2006;114(4):278-285. doi:10.1111/j.1600- 0722.2006.00380.x.

29. Sjögren U, Figdor D, Persson S, Sundqvist G. Influence of infection at the time of root filling on the outcome of endodontic treatment of teeth with apical periodontitis. Int En- dod J. 1997;30(5):297-306. doi:10.1111/j.1365-2591.1997. tb00714.x.

30. Radcliffe CE, Potouridou L, Qureshi R, et al. Antimicrobial activity of varying concentrations of sodium hypochlorite on the endodontic microorganisms Actinomyces israelii, siche naeslundii, Candida albicans and Enterococcus faeca- lis. Int Endod J. 2004;37(7):438-446. doi:10.1111/j.1365- 2591.2004.00752.x.

31. Gomes BP, Ferraz CC, Vianna ME, Berber VB, Teixeira FB, Souza-Filho FJ. In vitro antimicrobial activity of several concentrations of sodium hypochlorite and chlorhexidine gluconate in the elimination of Enterococcus faecalis. Int Endod J. 2001;34(6):424-428. doi:10.1046/j.1365-2591.2001.00410.x

32. Costeron JW, Lewandowski Z, Caldwell DE, Korber DR, Lappin-Scott HM. Microbial biofilms. Annu Rev Microbiol. 1995;49:711-45.

33. Costerton JW. Bacterial biofilms: a common cause of persistent infections. Science. 1999;284(5418):1318-22.

34. Hall-Stoodley L, Costerton JW, Stoodley P. Bacterial biofilms: from the natural environment to infectious diseases. Nat Rev Microbiol. 2004;2(2):95-108.

35. Hall-Stoodley L, Stoodley P. Evolving concepts in biofilm infections. Cell Microbiol. 2009;11(7):1034-43.

36. Hoiby N, Bjarnsholt T, Givskov M, Molin S, Ciofu O. Antibiotic resistance of bacterial biofilms. Int J Antimicrob Agents. 2010;35(4):322-32. 
37. Ricucci D, Siqueira Jr JF. Biofilms and apical periodontitis: study of prevalence and association with clinical and histopathologic findings. J Endod. 2010;36(8):127788.

38. Nair P. Light and electron microscopic studies on root canal $\mathrm{fl}$ ora and periapical lesions. J Endod. 1987;13: 29-39.

39. Chavez de Paz LE, Bergenholtz G, Svensater G. The effects of antimicrobials on endodontic biofilm bacteria. J Endod. 2010;36(1):70-7.

40. Clegg MS, Vertucci FJ, Walker C, Belanger M, Britto LR. The effect of exposure to irrigant solutions on apical dentin biofilms in vitro. J Endod. 2006;32(5):

434-7.

41. Dunavant TR, Regan JD, Glickman GN, Solomon ES, Honeyman AL.

Comparative evaluation of endodontic irrigants against Enterococcus faecalis biofilms. J Endod. 2006;32(6):527-31.

42. Larsen T. Susceptibility of Porphyromonas gingivalis in biofilms to amoxicillin, doxycycline and metronidazole. Oral Microbiol Immunol. 2002;17(5): 267-71.

43. Davey ME, O’Toole GA. Microbial biofilms: from ecology to molecular genetics. Microbiol Mol Biol Rev. 2000;64(4):847-67.

44. Jenkinson HF, Lappin-Scott HM. Biofilms adhere to stay. Trends Microbiol. 2001;9(1):9-10.

45. Gilbert P, Das J, Foley I. Biofilm susceptibility to antimicrobials. Adv Dent Res. 1997;11(1):160-7.

46. Johnson SA, Goddard PA, Iliffe C, Timmins B, Rickard AH, Robson G, Handley PS. Comparative susceptibility of resident and transient hand bacteria to para-chlorometa-xylenol and triclosan. J Appl Microbiol. 2002;93(2):336-44. 
47. Case PD, Bird PS, Kahler WA, George R, Walsh LJ. Treatment of root canal biofilms of Enterococcus faecalis with ozone gas and passive ultrasound activation. J Endod. 2012;38:523-6.

48. Gründling GL, Zechin JG, Jardim WM, de Oliveira SD, de Figueiredo JA. Effect of ultrasonics on Enterococcus faecalis biofilm in a bovine tooth model. J Endod. 2011;37:1128-33.

49. Joyce E, Phull SS, Lorimer JP, Mason TJ. The development and evaluation of ultrasound for the treatment of bacterial suspensions. A study of frequency, power and sonication time on cultured Bacillus species. Ultrason Sonochem. 2003;10:315-8.

50. Ordinola-Zapata R, Bramante CM, Aprecio RM, Handysides R, Jaramillo DE. Biofilm removal by $6 \%$ sodium hypochlorite activated by different irrigation techniques. Int Endod J. 2014;47(7):659-66.

51. Folwaczny M, Mehl A, Jordan C, Hickel R. Antibacterial effects of pulsed $\mathrm{Nd}$ :YAG laser radiation at different energy settings in root canals. J Endod. 2002;28:24-9.

52. Alsharhrani M, Divito E, Hughes C, Nathanson D, Huang G. Enhanced removal of enterococcus faecalis biofilms in the root canal using sodium hypochlorite plus Photon Induced Photoacoustic Streaming: an in vitro study. Photomed Laser Surg. 2014;32(5):

524-30.

53. Amato M, Pantaleo G, Abdellatif D, Blasi A, Gagliani M, Iandolo A. An in vitro evaluation of the degree of pulp tissue dissolution through different root canal irrigation protocols. J Cons. Dent. 2018 Mar-Apr; 21(2): 175-179. Doi: 10.4103/JCD.JCD_49_18. 
Pictures

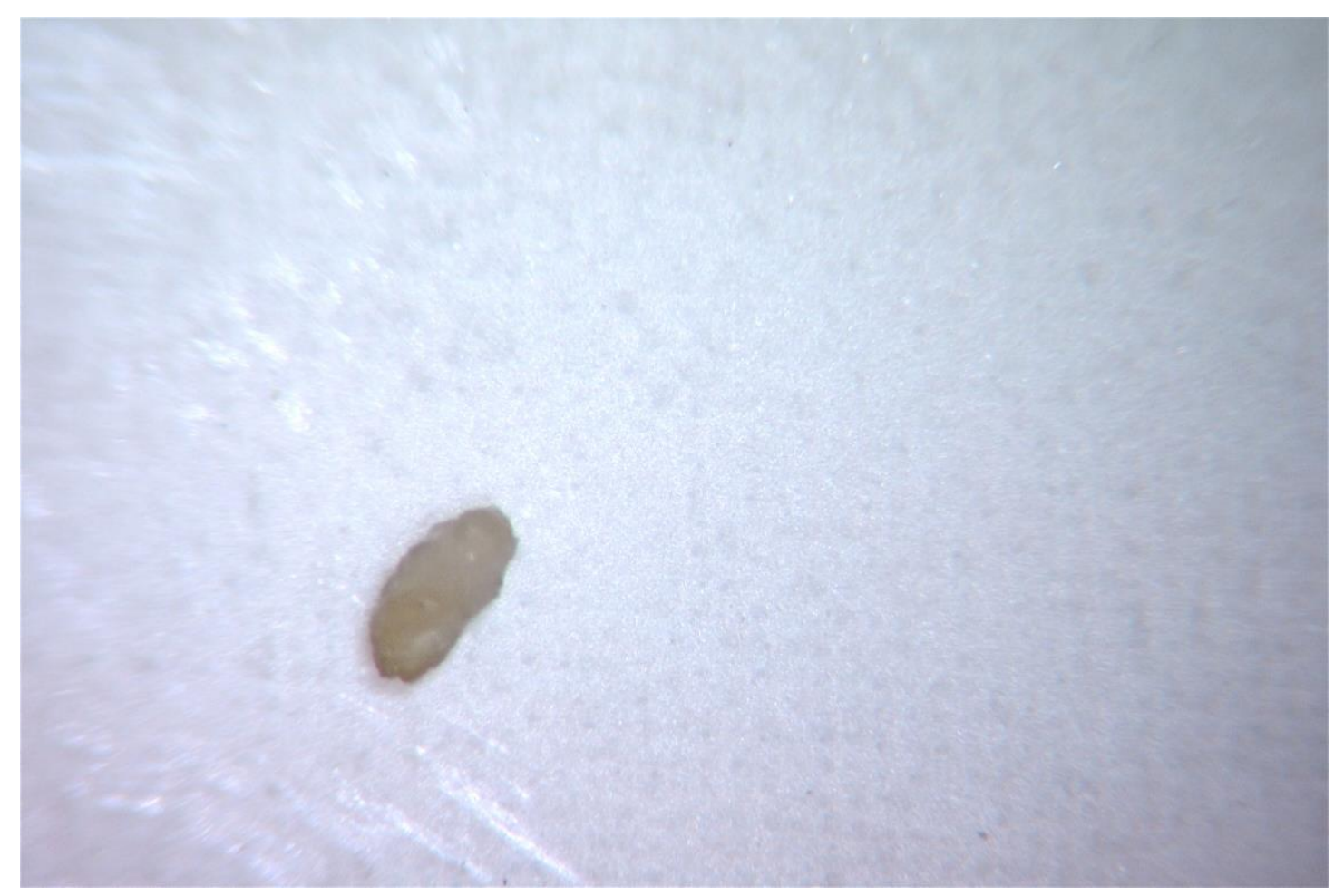

Fig. 1 Showing $0.1 \mathrm{mg}$ of pulp tissue 


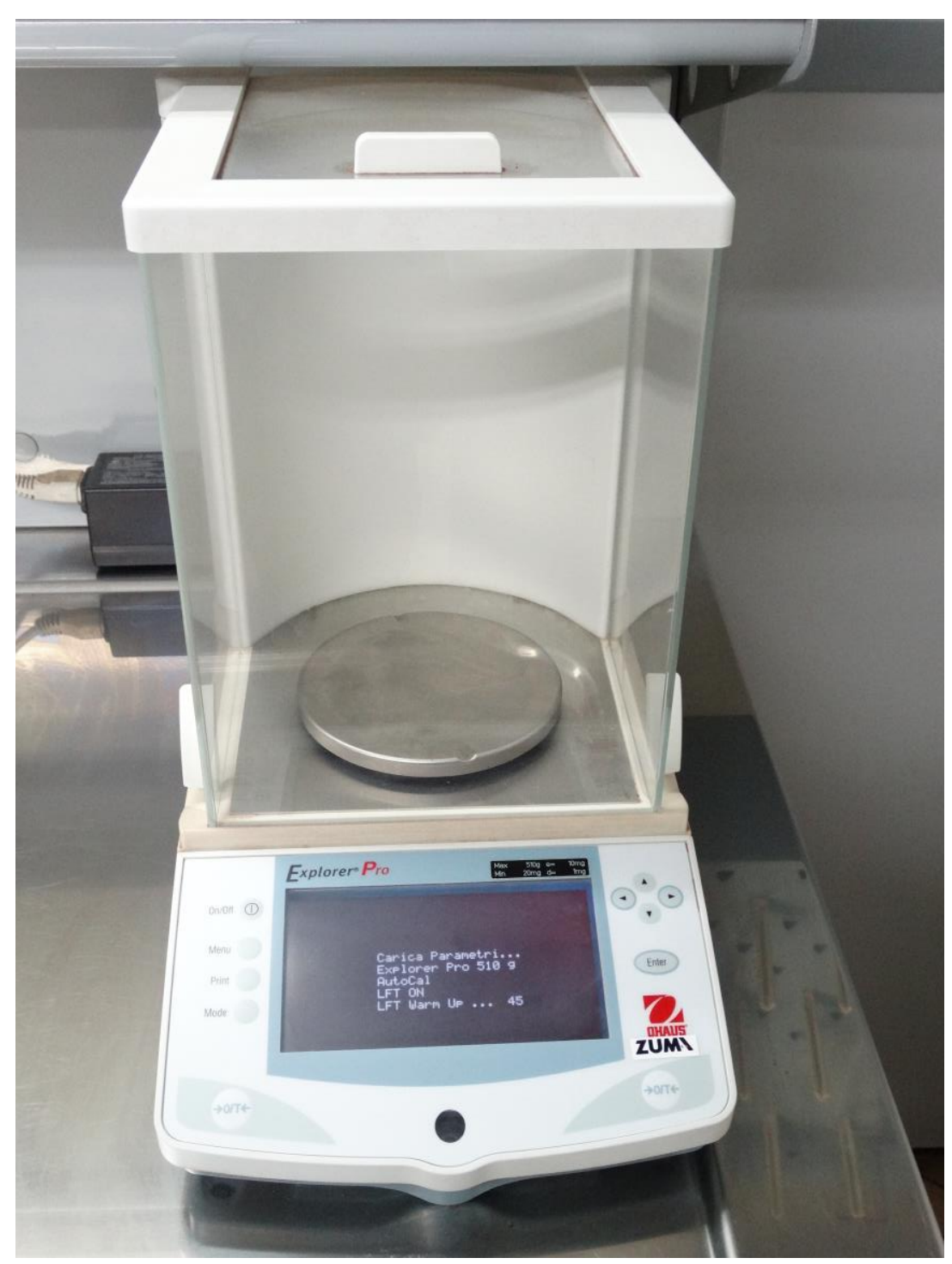

Fig.2 Professional balance 


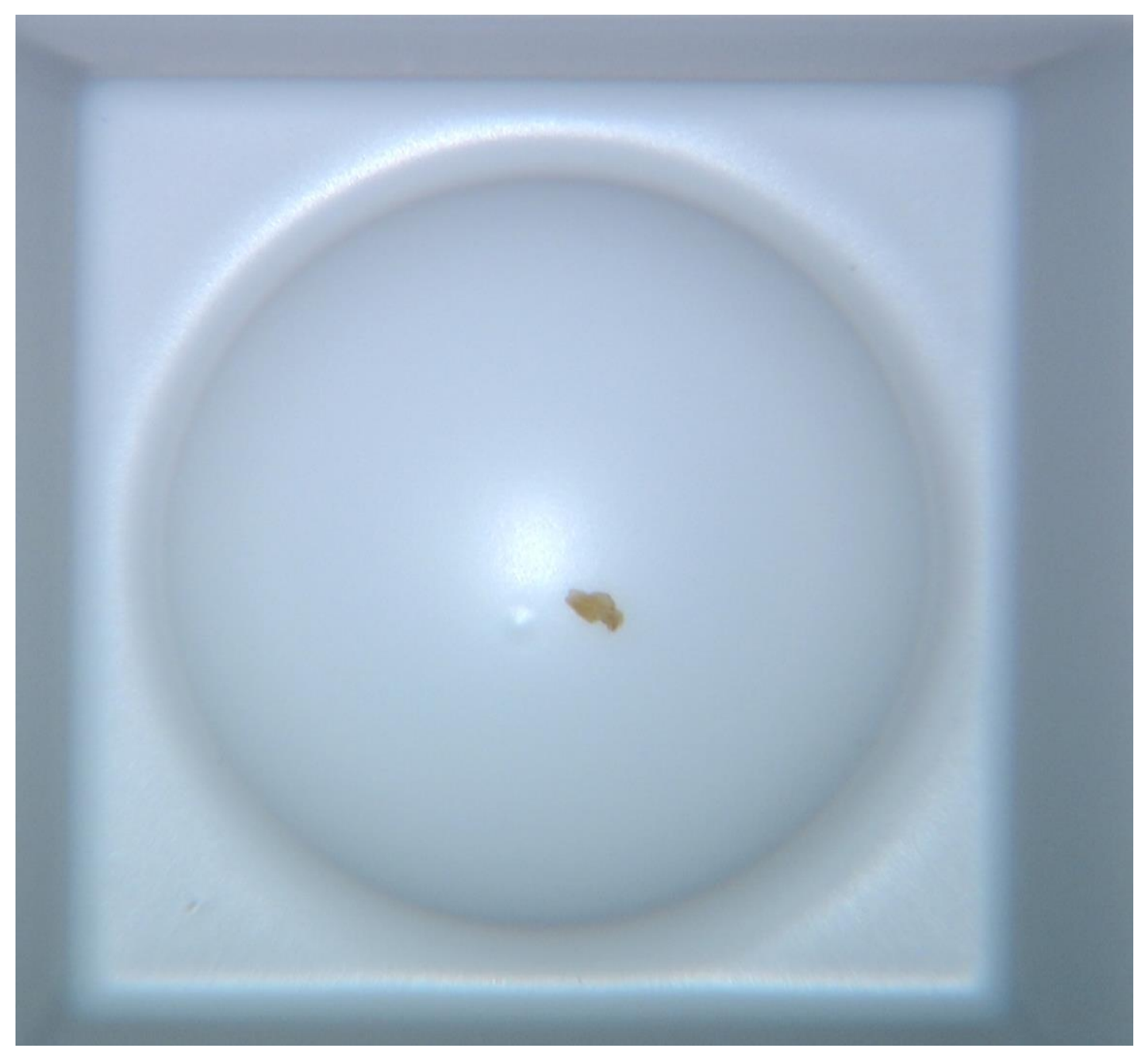

Fig.3 Showing $0.1 \mathrm{mg}$ of pulp tissue before inserting the irrigant 
Fig. 4 Showing $0.1 \mathrm{mg}$ of pulp tissue during dissolution 
Fig. 5 Showing the dissolution of the pulp tissue 
Fig. 6 Showing partial dissolution of the pulp tissue 
Fig. 7 Showing complete dissolution of the pulp tissue 


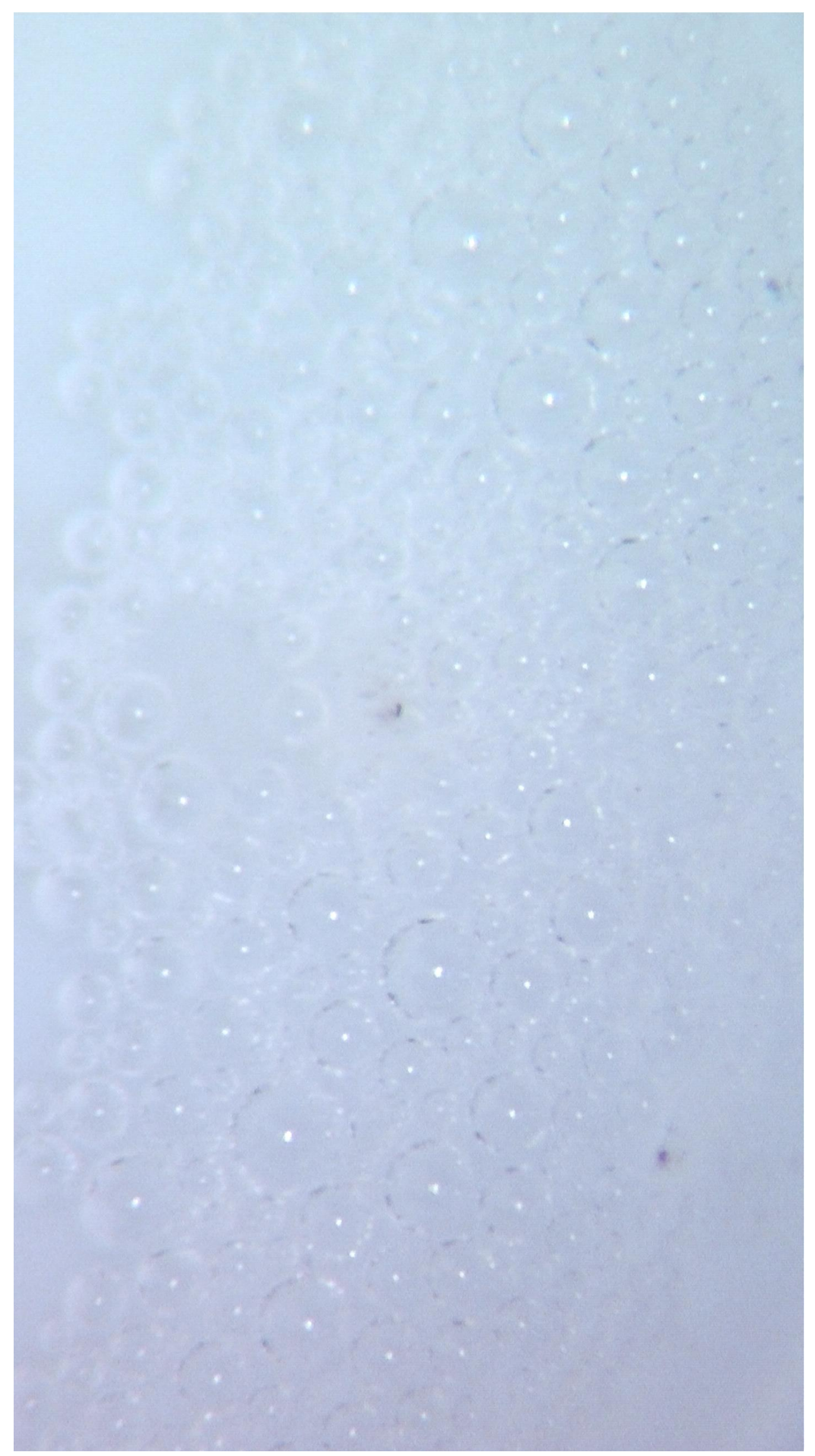


Fig. 8 increased magnification showing the complete dissolution of the pulp tissue and $\mathrm{NaOCl}$ in action 